\title{
MENINGKATKAN HASIL BELAJAR IPS SISWA KELAS VIII A SMP NEGERI 1 KAMBOWA MELALUI MODEL PEMBELAJARAN KOOPERATIF TIPE THINK PAIR SHARE PADA MATERI LINGKUNGAN HIDUP DAN PEMBANGUNAN BERKELANJUTAN
}

\author{
Fitriani Sidawanga ${ }^{1}$
}

\section{${ }^{1}$ Alumni Pendidikan Geografi FKIP UHO}

\begin{abstract}
Abstrak: Secara umum Penelitian ini bertujuan untuk meningkatkan hasil belajar IPS siswa kelas VIII A SMP Negeri 1 Kambowa melalui penerapan model pembelajaran kooperatif tipe Think Pair Share pada materi lingkungan hidup dan pembangunan berkelanjutan. Jenis penelitian ini adalah Penelitian Tindakan Kelas (PTK). Subyek penelitian ini adalah siswa kelas VIII A SMP Negeri 1 Kambowa yang terdaftar pada semester ganjil tahun pelajaran 2017/2018, yang berjumlah 26 orang. Dari hasil penelitian diperoleh kesimpulan bahwa: 1) aktivitas belajar siswa kelas VIII A SMP Negeri 1 kambowa yang di ajar dengan model Think Pair Share (TPS) adalah 2,7 yang berkategori cukup mengalami peningkatan pada siklus II mencapai 3,21 yang berkategori baik. 2) aktivitas mengajar guru pada siklus I adalah 2,67 kemudian pada siklus II Meningkat mencapai 3,28. 3) Hasil belajar IPS Terpadu siswa kelas VIII A SMP Negeri 1 Kambowa dapat ditingkatkan melalui model pembelajaran Kooperatif tipe Think Pair Share. Pada siklus I siswa yang tuntas 14 $(53,84 \%)$ dan tidak tuntas $12(46,15 \%)$ dengan rata-rata 63,84 sedangkan pada siklus kedua meningkat menjadi $22(84,61 \%)$ siswa yang tuntas dan $4(15,38 \%)$ siswa dinyatakan tidak tuntas dengan rata-rata 72,11 .
\end{abstract}

Kata kunci: Model Pembelajaran, Proses, Hasil Belajar 


\title{
IMPROVING STUDENT RESULTS IPS GRADE VIII A SMP NEGERI 1 KAMBOWA THROUGH COOPERATIVE LEARNING MODEL OF THINK PAIR SHARE TYPE ON ENVIRONMENTAL AND SUSTAINABLE DEVELOPMENT SUBJECT
}

\author{
Fitriani Sidawanga ${ }^{1}$
}

\section{${ }^{1}$ Alumnus Geografi Pendidikan Geografi FKIP UHO}

\begin{abstract}
In general, this study aims to improve the learning outcomes of IPS students of class VIII A SMP Negeri 1 Kambowa through the implementation of cooperative learning model Think Pair Share type on environmental material and sustainable development. This type of research is Classroom Action Research (PTK). The subject of this research is the students of class VIII A SMP Negeri 1 Kambowa registered in odd semester of academic year 2017/2018, which amounted to 26 people. From the result of the research, it can be concluded that: 1) the learning activity of the students of grade VIII A SMP Negeri 1 Kambowa which is taught with Think Pair Share (TPS) model is 2.7 which categorized enough to increase in cycle II reach 3,21 good categorized. 2) teacher teaching activity in cycle I is 2.67 then on cycle II Increase reaches 3.28. 3) The results of the study of Integrated Social Studies students of class VIII A SMP Negeri 1 Kambowa can be improved through cooperative learning model Think Pair Share type. In the first cycle of students who complete $14(53,84 \%)$ and unfinished 12 (46,15\%) with average 63,84 while in the second cycle increased to $22(84,61 \%)$ complete student and $4(15,38 \%)$ students expressed incomplete with an average of 72.11 .
\end{abstract}

Keywords: Learning Model, Process, Learning Outcomes

\section{PENDAHULUAN}

Pendidikan merupakan salah satu bagian yang penting dalam pembangunan nasional. Melalui pendidikan, dapat dikembangkan sumber daya manusia yang berkualitas dengan menguasai ilmu pengetahuan dan teknologi yang semakin berkembang.

Model pembelajaran yang melibatkan secara aktif menjadi pilihan model pembelajaran yang mendukung kurikulum (KTSP) yang memiliki prinsip pembelajaran berpusat pada pesetra didik, mengembangkan kreatifitas peserta didik, menciptakn kondisi yang menyenangkan dan menantang, mengembangkan beragam kemampuan yang bermuatan nilai, menyediakan pengalaman belajar yang beragam, dan belajar melalui Berbuat (learning by doing) (Wina Sanjaya, 2008).

Salah satu sumber daya manusia yang memiliki peran penting dalam dunia pendidikan adalah pengajar/pendidik atau yang lebih dikenal dengan sebutan guru. Sebagai pengajar atau pendidik, guru merupakan salah satufaktor penentu keberhasilan setiap upaya pendidikan. Itulah sebabnya setiap adanya inovasi pendidikan, khususnya dalam kurikulum dan peningkatan sumber daya manusia yang dihasilkan dari 
upaya pendidikan selalu bermuara kepada faktor guru. Hal ini menunjukan bahwa betapa pentingnya peran guru dalam dunia pendidikan.

Menurut Hasbullah (2009:10), lebih ringkas menguraikan tentang faktor-faktor pendidikan. Menurutnya faktor-faktor pendidikan dapat membentuk pola interaksi atau saling mempengaruhi satu sama lain.

\begin{tabular}{lrr}
\multicolumn{1}{c}{ Think Pair Share } & (TPS) \\
merupakan salah satu & tipe \\
pembelajaran kooperatif & yang \\
menekankan pada struktur-struktur \\
khusus yang dirancang untuk \\
mempengaruhi pola interaksi & siswa \\
dan memiliki tujuan & untuk \\
meningkatkan penguasaan materi & melajaran (Ibrahim, 2000:25).
\end{tabular}

Pembelajaran kooperatif tipe Think Pair Share memiliki prosedur yang memberi lebih banyak waktu kepada siswa untuk berpikir, menjawab, dan saling membantu satu sama lain (Nurhadi, 2003:66). Alasan pemilihan pembelajaran ini adalah supaya siswa dilatih bagaimana berdiskusi dalam kelompok untuk memecahkan masalah-masalah dalam pelajaran IPS, mengkontruksi sendiri konsep-konsep pelajaran IPS melalui bimbingan guru, dengan cara seperti ini maka siswa akan lebih mudah mengetahui jalinan keterkaitan antar konsep yang satu dengan konsep yang lainnya. Dengan demikian, siswa akan lebih muda untuk memahami tentang apa yang mereka pelajari dan tidak mudah untuk melupakannya.

Menurut Baharuddin dan Wahyuni (2012:12) belajar merupakan aktivitas yang dilakukan seseorang untuk mendapatkan perubahan dalam dirinya melalui pelatihan-pelatihan atau pengalaman-pengalaman. Sedangkan Gagne (dalam Suprijono, 2009:2) mengemukakan "Belajar adalah perubahan disposisi atau kemampuan yang dicapai seorang melalui aktivitas". Sementara itu, Slavin (dalam Rifa'I dan Anni, 2009:82) mengemukakan "Belajar merupakan perubahan individu yang disebabkan oleh pengalaman."

Menurut Gagne (dalam Rifa'I

dan Anni 2009:84-85) "Belajar merupakan sebuah sistem yang didalamnya terdapat berbagai unsur yang saling berhubungan sehingga menghasilkan tingkah laku." Unsurunsur tersebut meliputi: a.) Peserta didik b.) Stimulus c.) Memori.

Respon, Prinsip-prinsip Belajar:

Menurut Suprijono (2009:4) perubahan perilaku memiliki ciri-ciri: a.) Sebagai hasil tindakan rasional instrumental yaitu perubahan yang disadari. b.) Continue atau berkesinambungan dengan perilaku lainnya. c.) Fungsional atau bermanfaat sebagai bekal hidup. d.) Positif atau berakumulasi. e.) Aktif atau sebagai usaha yang direncanakan dan dilakukan. f.) Permanen atau tetap. g.) Bertujuan dan terarah. h.) Mencakup keseluruhan potensi kemanusiaan.

Faktor yang mempengaruhi belajar menurut Baharuddin dan Wahyuni (2012:19) antara lain faktor internal dan faktor eksternal. Faktor internal meliputi faktor fisiologis dan faktor psikologis. Faktor fisiologis adalah faktoryang berhubungan dengan kondisi fisik individu sedangkan faktor psikologis adalah keadaan psikologi seseorang seperti kecerdasan, minat, bakat, dan motivasi. Faktor eksternal meliputi faktor lingkungan sosial dan lingkungan non sosial.

Menurut Sagala pembelajaran adalah komunikasi dua arah untuk membelajarkan peserta didik menggunakan asas pendidikan maupun teori belajar. Sedangkan pembelajaran menurut Suprijono 


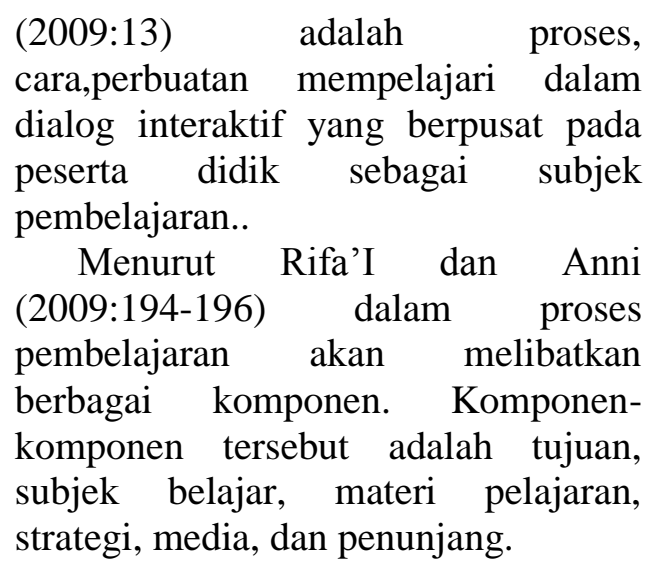

\section{Aktivitas Siswa}

Menurut Hamalik (2002:34), aktivitas belajar adalah suatu proses atau kegiatan yang dilakukan untuk mencapai pengetahuan, keterampilan, nilai dan sikap. Dari uraian di atas aktivitas siswa adalah segala bentuk kegiatan pembelajaran untuk mencapai pengetahuan, ketrampilan, nilai, dan sikap.

Menurut Diedrich (dalam Hamalik, 2009:21) ada 8 macam kegiatan yang dilakukan peserta didik pada saat pembelajaran meliputi aktivitas jasmani dan aktivitas jiwa. Aktivitas-aktivitas tersebut adalah: a) kegiatan visual antaralain: membaca, melihat gambar-gambar, mengamati eksperimen, demontrasi, pameran, dan mengamati orang lain bekerja atau bermain. b) kegiatan lisan/moral antara lain: mengemukakan suatu fakta atau prinsip, menghubungkan suatu kejadian, mengajukan pertanyaan, saran, mengajukan pendapat, wawancara, diskusi dan interupsi. c) kegiatan mendengarkan antara lain: mendengarkan penyajian bahan, mendengar percakapan/diskusi kelompok, mendengarkan suatu permainan, mendengar radio. d) kegiatan menulis antara lain: menulis cerita, karangan, laporan, tes, angket, menyalin dan sebagainya. e) kegiatan menggambarkan antara lain: menggambar, membuat grafik, peta, diagram, pola dan sebagainya. f) kegiatan motorik antara lain: melakukan percobaan, membuat kontruksi, model, mereparasi, bermain, berkebun, memelihara binatang dan sebagainya. g) kegiatan mental antara lain: menanggapi, mengingat, memecahkan soal, menganalisis, melihat hubungan, mengambil keputusan dan sebagainya. h) kegiatan emosional antara lain: menaruh minat, merasa bosan, gembira, berani, tenang, gugup dan sebagainya.

\section{Hasil Belajar}

Menurut Rusmono (2012:10) hasil belajar adalah perubahan perilaku individu yang meliputi ranah kognitif, afektif, dan psikomotorik. Perubahan perilaku tersebut diperoleh setelah siswa menyelesaikan program pembelajarannya melalui interaksi dengan berbagai sumber belajar dan lingkungan belajar. Menurut Rifa'I dan Anni (2009:85) hasil belajar merupakan perubahan perilaku yang diperoleh peserta didik setelah mengalami kegiatan belajar. Perolehan aspek-aspek perubahan perilaku tersebut tergantung pada apa yang dipelajari oleh peserta didik, oleh karena itu apabila peserta didik mempelajari tentang konsep maka perubahan perilaku yang diperoleh adalah berupa penguasaan konsep. Dan menurut Suprijono (2009:7) hasil belajar adalah perubahan perilaku secara keseluruhan bukan hanya salah satu aspek potensi kemanusiaan saja.

Menurut Bloom (dalam Rusmono 2012:8) hasil belajar adalah perubahan perilaku yang meliputi tiga ranah yaitu ranah kognitif, afektif, dan psikomotorik. Ranah kognitif meliputi tujuan-tujuan belajar yang 
berhubungan dengan pengetahuan dan pengembangan kemampuan intelektual dan ketrampilan. Ranah afektif meliputi tujuan-tujuan belajar yang menjelaskan perubahan perilaku sikap, minat, nilai-nilai, dan pengembangan apresiasi serta penyesuaian. Ranah psikomotorik mencakup perubahan perilaku yang menunjukkan bahwa siswa telah mempelajari ketrampilanketrampilan fisik tertentu.

Menurut Baharuddin dan Wahyuni (2012;19-26) hasil belajar secara umum dipengaruhi oleh dua faktor yaitu faktor internal dan faktor eksternal. Kedua faktor tersebut saling mempengaruhi dalam pembelajaran sehingga menentukan kualitas hasil belajar. Faktor internal adalah faktorfaktor yang berasal dari diri individu yang meliputi faktor fisiologis dan faktor Psikologis. Sedangkan faktor eksternal adalah faktor-faktor yang berasal dari luar individu.

Menurut Syah (dalam

Baharuddin dan Wahyuni, 2012:26) faktor eksteranal yang mempengaruhi hasil belajar meliputi faktor lingkungan sosial dan faktorlingkungan nonsosial. Menurut Gagne (dalam Suprijono 2009:5-6) hasil belajar berupa: a.) Informasi verbal, yaitu kemampuan mengungkapkan pengetahuan dalam bentuk bahasa, baik lisan maupun tertulis. b.) Keterampilan intelektual, yaitu kemampuan memaparkan konsep dan lambang. c.) Strategi kognitif, yaitu kecakapan menyalurkan dan mengarahkan aktivitaskognitifnya sendiri. d.) Keterampilan motorik, yaitu kemampuan melakukan serangkaian gerak jasmani dalam urusan dan koordinasi, sehingga terwujud otomatisme gerak jasmani. e.) Sikap, yaitu kemampuan menerima atau menolak objek berdasarkan penilaian terhadap objek tersebut.

Berpikir berpasangan berempat (Think-Pair-Share) yaitu model yang dikembangkan oleh Frank lyman dan Spencer Kegen (dalam Isjoni 2009:67) (Think-Pair-Share) dimana model ini memberikan kesempatan untuk bekerja sendiri serta bekerja sama dengan orang lain. Keunggulan dari model ini adalah optimalisasi pertisipasi siswa, yaitu memberi kesempatan delapan kali lebih banyak kepada setiap siswa untuk dikenali dan menunjukan partisipasi mereka kepada orang lain.

\section{Langkah-Langkah Model Pembelajaran Think Pair Share (TPS)}

Adapun langkah dalam pembelajaran Think Pair Share (TPS) adalah: (1) guru membagi siswa dalam kelompok berempat dan memberikan tugas kepada semua kelompok, (2) Setiap siswa memikirkan dan mengerjakan tugas tersebut sendiri, (3) siswa berpasangan dengan salah satu rekan dalam kelompok dan berdiskusi dengan pasangannya, (4) kedua pasangan bertemu kembali dalam kelompok berempat. Siswa mempunyai kesempatan untuk membagikan hasil kerjanya kepada kelompok berempat Lie (2004:58).

Menurut Nurhadi (2003:65), akuntabilitas berkembang karena setiap siswa harus saling melaporkan hasil pemikiran masing-masing dan berbagi dengan seluruh kelas. Jumlah anggota kelompok yang kecil mendorong setiap anggota untuk terlibat secara aktif, sehingga siswa yang jarang atau bahkan tidak pernah berbicara di depan kelas paling tidak memberi ide atau jawaban kepada pasangannya.

METODE PENELITIAN 


\begin{tabular}{|c|c|}
\hline Penelitian ini & telah \\
\hline dilaksanakan pada semester & ganjil \\
\hline tahun ajaran 2017/2018 & yang \\
\hline $\begin{array}{l}\text { bertempat dikelas VIII A SMP } \\
1 \text { Kambowa. }\end{array}$ & Negeri \\
\hline
\end{tabular}

Subyek penilitian ini siswa kelas VIII A yang berjumlah 26 orang yang terdiri 12 siswa laki-laki dan 14 orang siswa perempuan. Penelitian ini dilakukan dikelas VIII A karena pada kelas tersebut masih tergolong rendah dibandingkan dengan kelas VIII lainnya karena guru masih dominan menggunakan metode ceramah yang cenderung siswa kurang aktif dalam proses belajar mengajar.

Jenis penelitian ini adalah penelitian tindakan kelas (PTK) yang dilakukan oleh guru didalam kelasnya sendiri melalui refleksi dengan tujuan untuk memperbaiki kinerjanya sebagai guru sehingga hasil belajar siswa meningkat.

Sumber data penelitian adalah guru dan siswa meliputi: a) hasil obeservasi aktivitas belajar siswa, b) hasil observasi aktivitas mengajar guru, dan c) hasil belajar siswa.

Data dikumpulkan dari hasil tindakan yang dilakukan pada proses observasi, proses belajar-mengajar, tes hasil balajar, dan refleksi yang dijabarkan sebagai berikut: 1)Data tentang kondisi pelaksanaan Model Pembelajaran Kooperatif Tipe Think pair share diambil dengan menggunakan lembar observasi aktivitas siswa dan guru. 2) Data tentang hasil belajar IPS diambil dengan menggunakan tes hasil belajar (tes siklus) dengan bentuk tes berupa esay yang mencakup semua indikator pembelajaran pada siklus I dan siklus II.

Data dalam penelitian ini dianalisis menggunakan deskripstif kualitatif dan kuantitatif. Analisis deskriptif kualitatif digunakan untuk memberikan penjelasan mengenai aktivitas siswa serta kemampuan guru selama proses pembelajaran berlangsung. Sedangkan analisis deskriptif kuantitatif digunakan untuk menyajikan presentase aktivitas guru dalam mengelola pembelajaran, presentase aktivitas siswa dan presentase ketuntasan hasil belajar siswa.

\section{HASIL PENELITIAN}

a. Data aktifitas belajar siswa siklus I

Data mengenai hasil aktivitas belajar siswa kelas VIII A SMP Negeri 1 kambowa selama proses pembelajaran IPS melalui model pembelajaran kooperatif tipe Think Pair Share pada materi lingkungan hidup dan pembangunan berkelanjutan diperolah dengan menggunakan lembar observasi aktivitas belajar siswa. Untuk mengetahui ketercapaian indikator dalam lembar observasi aktivitas siswa diberikan skor keterlaksanaan untuk setiap aktivitas yang dilakukan siswa selama proses pembelajaran yang dimulai dengan Skor 1 sampai 4. Data mengenai penskoran aktivitas belajar siswa dalam kegiatan belajar mengajar pada siklus I dapat dilihat pada tabel berikut: 


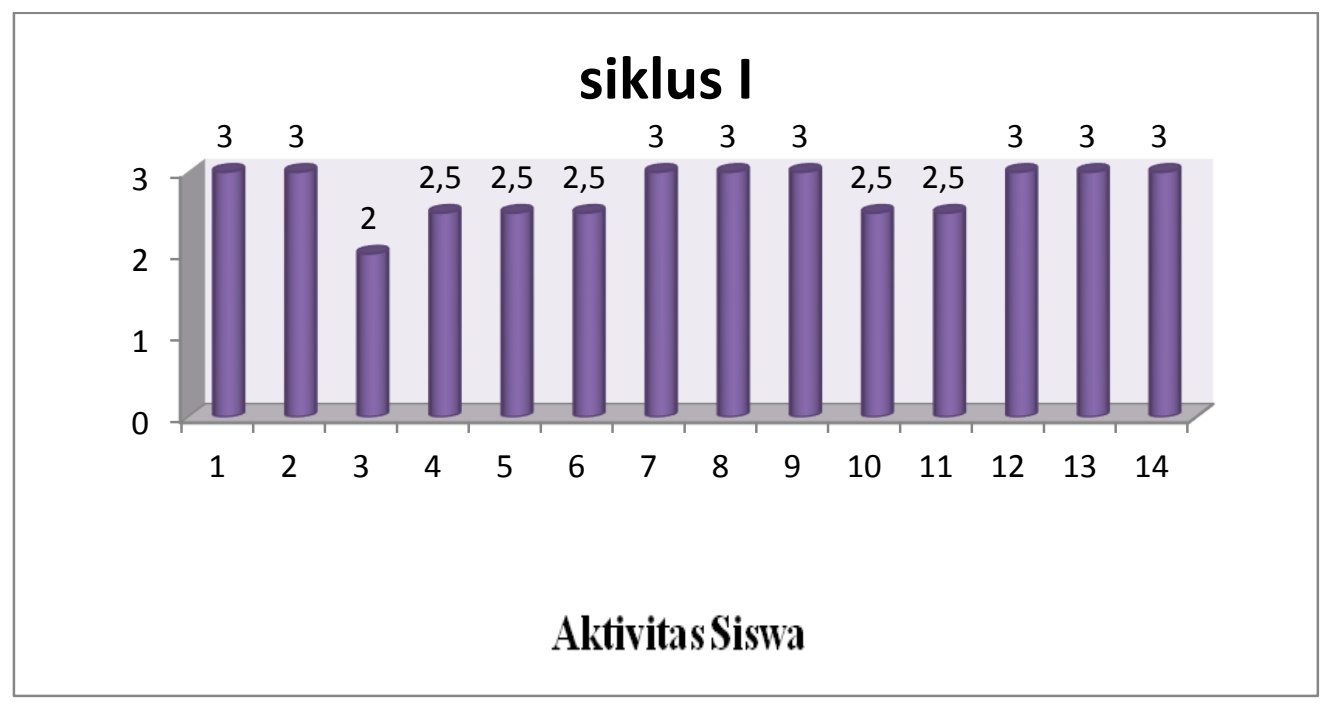

Gambar 3.1. Grafik skor rata-rata aktifitas belajar siswa siklus 1

Keterangan gambar:1) Siswa menjawab salam 2) Siswa duduk siap dan berdoa 3) Siswa menyimak dengan fokus saat pemeriksaan kehadiran dan menyiapkan diri untuk belajar 4) Siswa termotivasi untuk belajar 5) Siswa mendengarkan penyampaian tujuan pembelajaran yang akan di capai 6) Siswa menyimak dengan seksama pertanyaan yang berhubungan dengan materi yang akan disampaikan 7) Siswa diberi kesempatan untuk memikirkan sendiri jawaban dari permasalahan yang disampaikan guru dengan menuliskan hasil pemikiran masing-masing 8) siswa mendiskusikan hasil masingmasing dengan pasangannya 9) Siswa berbagi jawaban dengan seluruh kelas
10) Siswa melakukan refleksi atau evaluasi terhadap hasil pemecahan masalah yang telah mereka diskusikan 11) Siswa menyimpulkan pelajaran 12) Siswa menulis sosal untuk dikerjakan dirumah 13) Siswa mendengarkan penyampaian materi yang harus dipelajari untuk pertemuan berikutnya 14) Siswa menjawab salam.

\section{b. Data aktivitas guru siklus I}

Data mengenai aktifitas guru dalam mengelola pembelajaran dengan penerapan model pembelajaran Think Pair Share (TPS) diperoleh dengan menggunakan lembar observasi aktivitas guru pada siklus I dapat dilihat pada tabel berikut: 


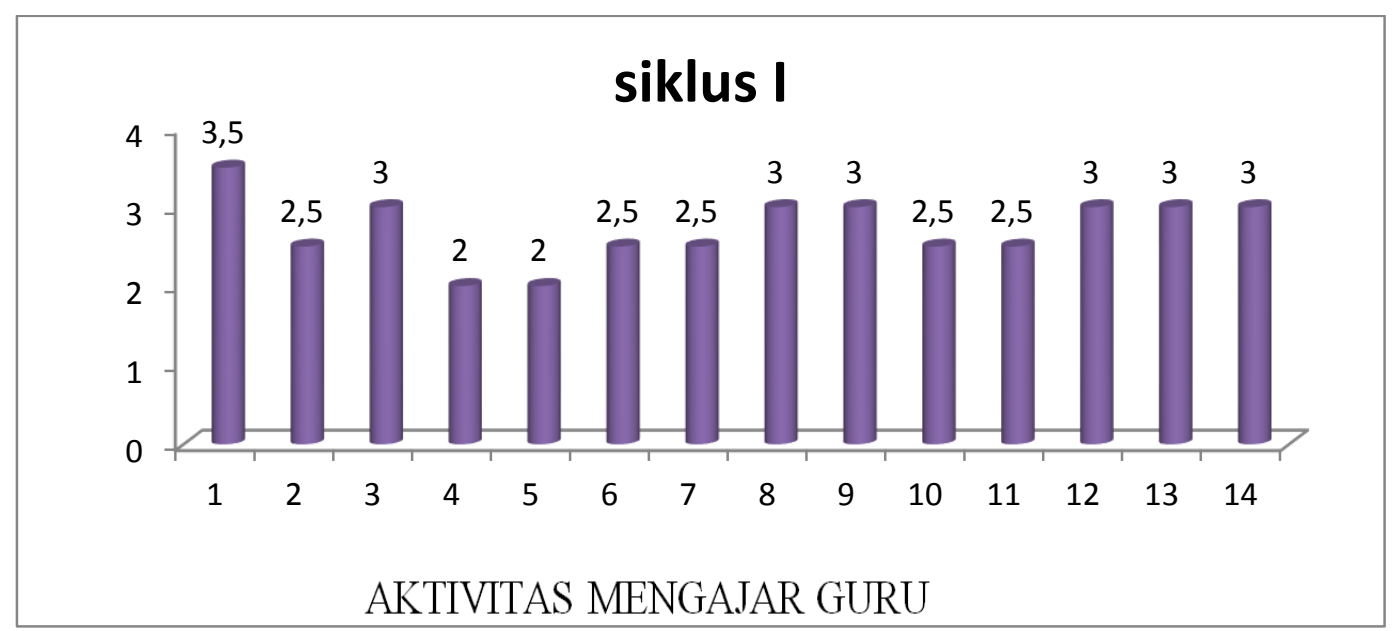

Gambar 3.2 grafik skor rata-rata akitivitas mengajar guru siklus I

Keterangan gambar: 1) Guru menyampaikan salam dan menyapa peserta didik 2) Guru mempersilahkan siswa berdoa 3) Guru memeriksa kehadiran siswa 4) Guru memberikan memotivasi kepada siswa 5) Guru menyampaikan tujuan pembelajaran yang akan dicapai 6) Guru menyampaikan pertanyaan yang behubungan dengan materi yang akan disampaikan 7) Guru memberi kesempatan kepada siswa untuk memikirkan sendiri jawaban dari permasalahan yang disampaikan dan meminta siswa untuk menulisakn hasil pemikiran masing-masing 8) Guru mengorganisasikan siswa untuk berpasangan dan memberi kesempatan kepada siswa untuk mendikusikan jawaban yang menurut mereka paling benar atau paling meyakinkan 9) Guru mempersilahkan siswa untuk berbagi jawaban dengan seluruh kelas 10) Guru membantu siswa untuk melakukan refleksis atau evaluasi terhadap hasil pemecahan masalah yang telah mereka diskusikan 11) Guru membimbing siswa untuk menyimpulkan pelajaran 12) Guru memberikan soal latihan untuk dikerjakan dirumah 13) Guru memberitahukan materi yang harus dipelajari untuk pertemuan selanjutnya 14) Guru mengucap salam menutup kegiatan pembelajaran.

\section{c. Data hasil belajar siswa siklus I}

Data hasil belajar IPS siswa kelas VIII A pada materi lingkungan hidup dan pembangunan berkelanjutan diperoleh dengan menggunakan lembar tes hasil belajar berupa soal essay test. Kegiatan evaluasi ini dilakukan untuk mengetahui kemampuan siswa terhadap materi yang telah dipelajari dengan menggunakan metode Thin Pair Share. Adapun data hasil belajar siswa pada siklus I selengkapnya dapat dilihat pada tabel sebagai berikut:

\begin{tabular}{llll}
\hline Skor & Jumlah siswa & persentase & Kentuntasan belajar \\
\hline $0-64$ & 12 orang & $46,15 \%$ & Belum Tuntas \\
\hline $65-100$ & 14 orng & $53,84 \%$ & Sudah Tuntas \\
\hline Jumlah & 26 orang & & \\
\hline Keterangan: & & & \\
\hline
\end{tabular}


Jurnal Penelitian Pendidikan Geografi Volume 3 No. 4 Oktober 2018

\begin{tabular}{ll}
\hline Tindak tuntas & $: 12$ orang \\
\hline Tuntas & $: 14$ orang \\
\hline Nilai rata-rata & $: 63,84$ \\
\hline Nilai tertinggi & $: 80$ \\
\hline Nilai terendah & $: 40$ \\
\hline Presentase ketuntasan & $: 53,84 \%$ \\
\hline
\end{tabular}

\section{Tabel 3.1 Data Analisis Ketuntasan Hasil Belajar Siswa Siklus I}

Sumber:SMPN 1 KAMBOWA 2017

Gambaran hasil belajar IPS siswa kelas VIII A yang di ajar dengan menerapkan model pembelajaran

Think Pair Share (TPS) pada siklus I dapat dilihat pada gambar berikut:

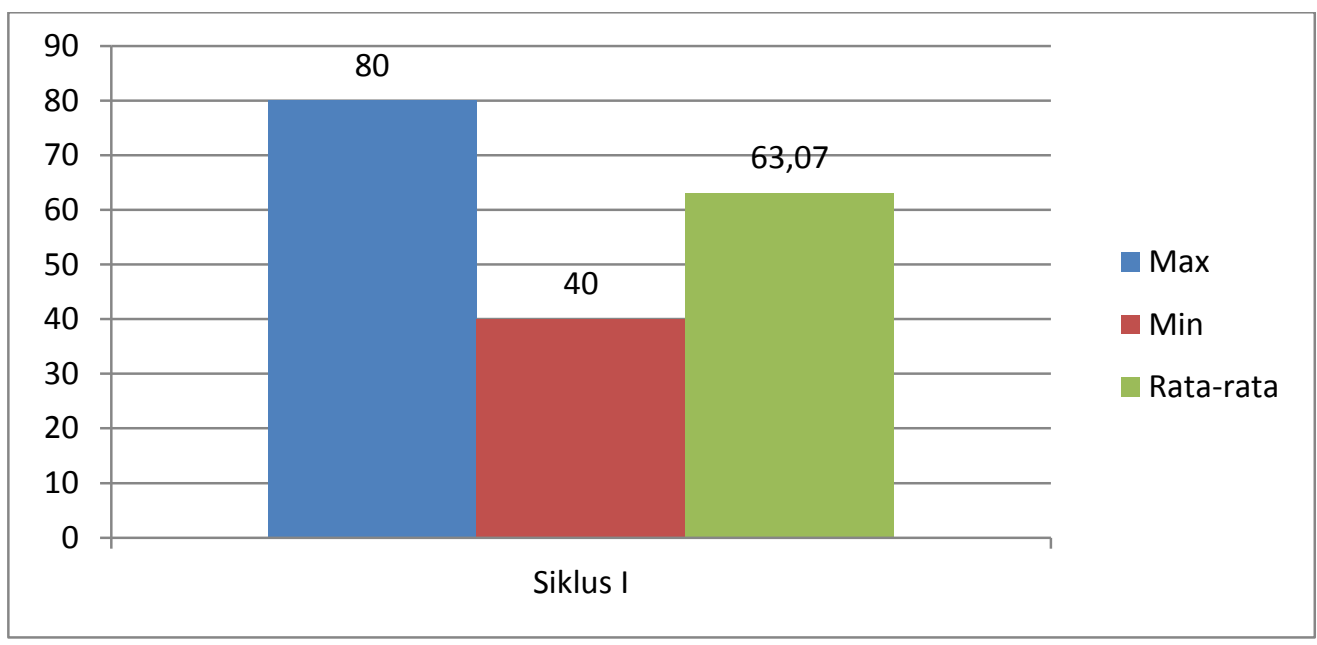

\section{Gambar 3.3 Grafik Nilai Hasil Belajar Siklus I}

\section{d. Data aktivitas belajar siswa siklus II}

Data mengenai hasil aktivitas belajar siswa kelas VIII A SMP Negeri 1 kambowa selama proses pembelajaran IPS melalui model pembelajaran kooperatif tipe Think Pair Share pada materi lingkungan hidup dan pembangunan berkelanjutan diperolah dengan menggunakan lembar observasi aktivitas belajar siswa. Untuk mengetahui ketercapaian indikator dalam lembar observasi aktivitas siswa diberikan skor keterlaksanaan untuk setiap aktivitas yang dilakukan siswa selama proses pembelajaran yang dimulai dengan Skor 1 sampai 4. Data mengenai penskoran aktivitas belajar siswa dalam kegiatan belajar mengajar pada siklus II dapat dilihat pada gambar dibawah ini: 


\section{SIKLUS II}

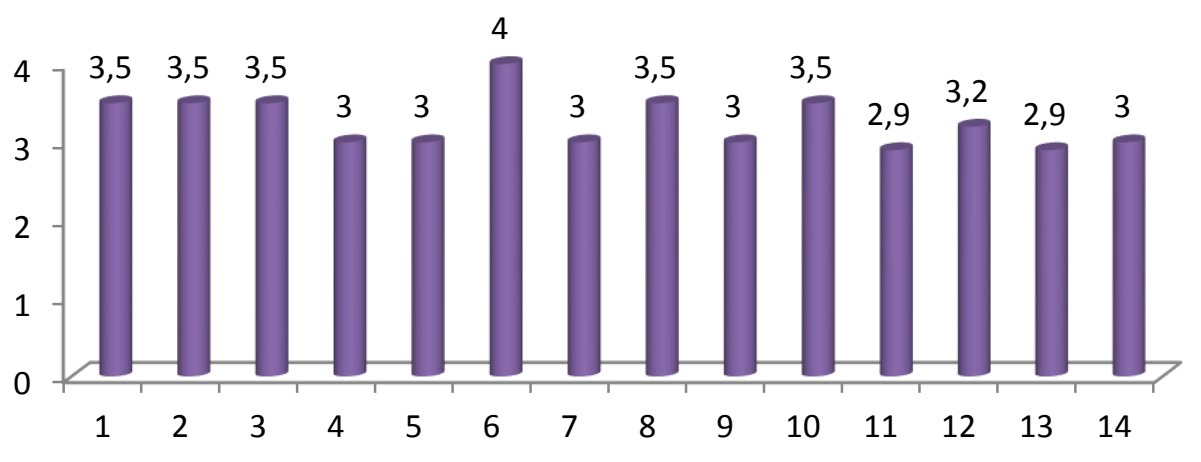

\section{Aktivitas Siswa}

\section{Gambar 3.4 grafik skor rata-rata aktifitas belajar siswa siklus II}

Keterangan gambar:1) Siswa menjawab salam 2) Siswa duduk siap dan berdoa 3) Siswa menyimak dengan fokus saat pemeriksaan kehadiran dan menyiapkan diri untuk belajar 4) Siswa termotivasi untuk belajar 5) Siswa mendengarkan penyampaian tujuan pembelajaran yang akan di capai 6) Siswa menyimak dengan seksama pertanyaan yang berhubungan dengan materi yang akan disampaikan 7) Siswa diberi kesempatan untuk memikirkan sendiri jawaban dari permasalahan yang disampaikan guru dengan menuliskan hasil pemikiran masing-masing 8) siswa mendiskusikan hasil masingmasing dengan pasangannya 9) Siswa berbagi jawaban dengan seluruh kelas 10) Siswa melakukan refleksi atau evaluasi terhadap hasil pemecahan masalah yang telah mereka diskusikan 11) Siswa menyimpulkan pelajaran 12) Siswa menulis sosal untuk dikerjakan dirumah 13) Siswa mendengarkan penyampaian materi yang harus dipelajari untuk pertemuan berikutnya 14) Siswa menjawab salam

Gambaran rata-rata aktifitas belajar siswa selama pembelajaran pada siklus I pertemuan I dan II dapat dilihat pada gambar berikut:

\section{e. Data aktivitas guru siklus II}

Gambaran aktifitas guru dalam mengelola pembelajaran dengan penerapan model pembelajaran Think Pair Share (TPS) diperoleh dengan menggunakan lembar observasi aktivitas guru pada siklus II dapat dilihat pada gambar berikut: 


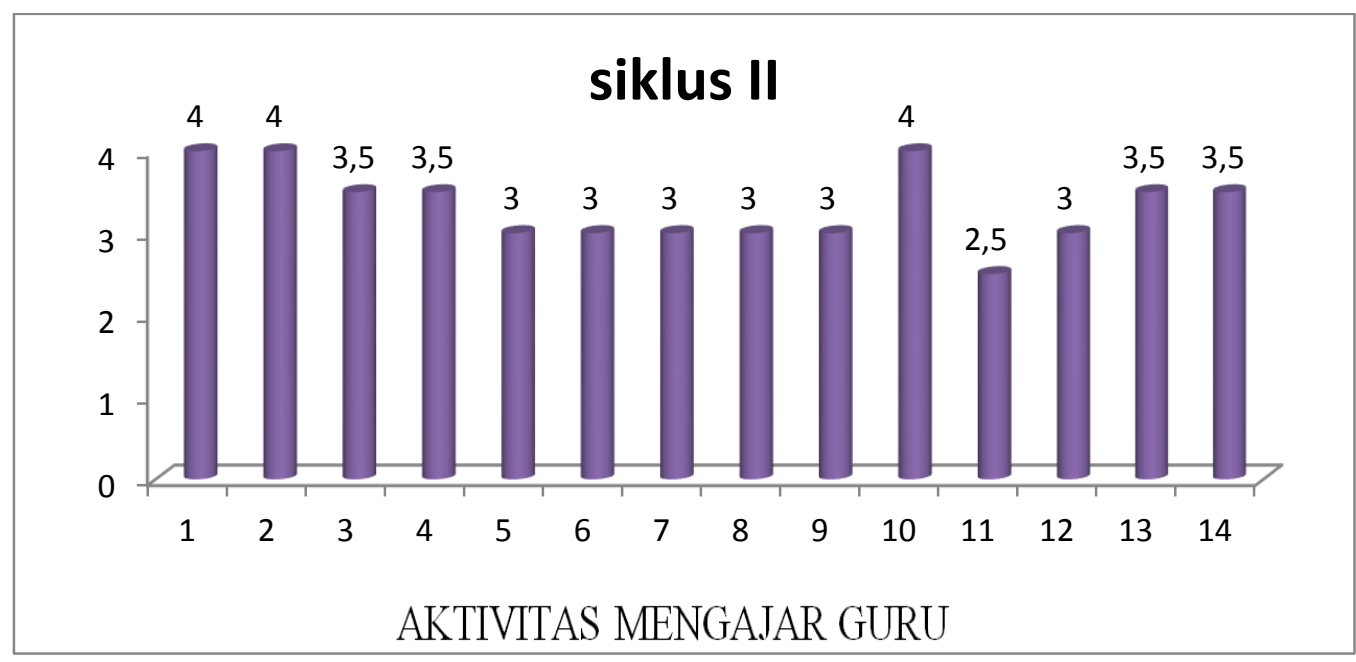

\section{Gambar 3.5 grafik skor rata-rata akitivitas mengajar guru siklus II}

Keterangan gambar: 1) Guru menyampaikan salam dan menyapa peserta didik. 2) Guru mempersilahkan siswa berdoa 3) Guru memeriksa kehadiran siswa 4) Guru memberikan memotivasi kepada siswa 5) Guru menyampaikan tujuan pembelajaran yang akan dicapai 6) Guru menyampaikan pertanyaan yang behubungan dengan materi yang akan disampaikan 7) Guru memberi kesempatan kepada siswa untuk memikirkan sendiri jawaban dari permasalahan yang disampaikan dan meminta siswa untuk menulisakn hasil pemikiran masing-masing 8) Guru mengorganisasikan siswa untuk berpasangan dan memberi kesempatan kepada siswa untuk mendikusikan jawaban yang menurut mereka paling benar atau paling meyakinkan 9) Guru mempersilahkan siswa untuk berbagi jawaban dengan seluruh kelas 10) Guru membantu siswa untuk melakukan refleksis atau evaluasi terhadap hasil pemecahan masalah yang telah mereka diskusikan 11) Guru membimbing siswa untuk menyimpulkan pelajaran 12) Guru memberikan soal latihan untuk dikerjakan dirumah 13) Guru memberitahukan materi yang harus dipelajari untuk pertemuan selanjutnya 14) Guru mengucap salam menutup kegiatan pembelajaran.

\section{f. Data hasil belajar siswa siklus II}

Data hasil belajar IPS siswa kelas VIII A SMP Negeri 1 Kambowa pada materi lingkungan hidup dan pembangunan berkelanjutan diperoleh dengan menggunakan lembar tes hasil belajar berupa soal uarain yang diberikan pada akhir siklus. Berdasarkan hasil analisis terhadap hasil belajr siswa pada sisklus II diperoleh data seperti yang tertera pada gambar berikut:

\begin{tabular}{llll}
\hline Skor & Jumlah siswa & persentase & Kentuntasan belajar \\
\hline $0-64$ & 4 orang & $15,38 \%$ & Belum Tuntas \\
\hline $65-100$ & 22 orang & $84,61 \%$ & Sudah Tuntas \\
\hline Jumlah & 26 orang & & \\
\hline
\end{tabular}


Jurnal Penelitian Pendidikan Geografi Volume 3 No. 4 Oktober 2018

\begin{tabular}{ll}
\hline Keterangan: & \\
\hline Tindak tuntas & $: 4$ orang \\
\hline Tuntas & $: 22$ orang \\
\hline Nilai rata-rata & $: 72,11$ \\
\hline Nilai tertinggi & $: 90$ \\
\hline Nilai terendah & $: 50$ \\
\hline Presentase ketuntasan & $: 84,38 \%$ \\
\hline
\end{tabular}

Tabel 3.2 Data Analisis Ketuntasan Hasil Belajar Siswa Siklus II Sumber:SMPN 1 KAMBOWA 2017

Untuk lebih jelasnya mengenai gambaran hasil belajar IPS siswa kelas VIII A yang di ajar dengan menerapkan model pembelajaran Think Pair Share (TPS) pada siklus II dapat dilihat pada gambar berikut:

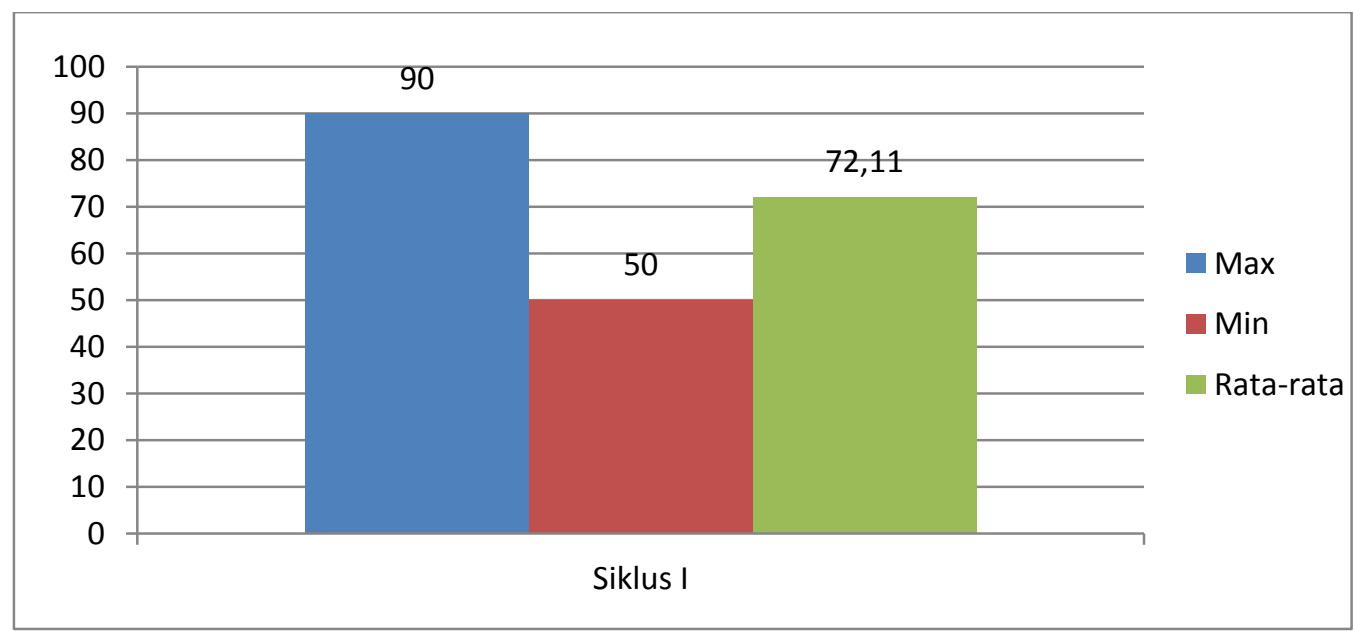

Gambar 3.6 Grafik Nilai Hasil Belajar Siklus II

Selajutnya berdasarkan analisis persentase ketuntasan belajar siswa sebagaimana disajikan pada gambar pada siklus I diperoleh hasil berikut: 


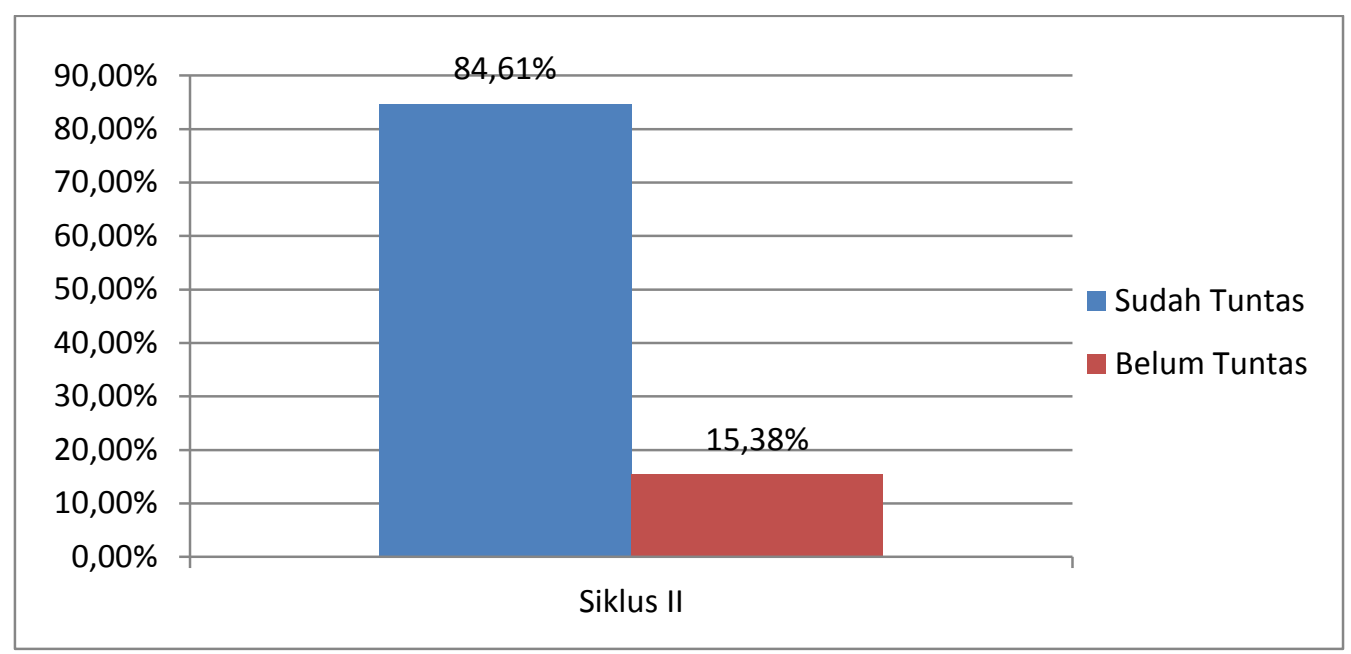

\section{Gambar 3.7 Grafik Presentase Ketuntasan Siswa Siklus II}

Gambar diatas menunjukan bahwa ketuntasan belajar siswa pada siklus II yang telah memperoleh skor antara 0-64 berjumlah 4 orang dengan persentase $15,38 \%$, sedangkan siswa yang telah memperoleh skor antara 65 100 berjumlah 22 orang dengan persentase $84,61 \%$.hasil ini sudah lebih baik jika dibandingkan dengan skor perolehan nilai siswa pada siklus I. Dalam hal indikator ketuntasan belajar siswa telah tercapai atau berhasil, dimana secara klasikal, yaitu jika nilai siswa yang telah mencapai KKM (65) adalah 80\%, maka dikatakan hasil penelitian telah tercapai dan berhasil.

\section{PEMBAHASAN}

\section{Aktivitas Belajar Siswa Selama KBM Berlangsung}

Berdasarkan permasalahan pertama tentang bagaimana gambaran aktivitas belajar siswa kelas VIII A SMP Negeri 1 Kambowa dalam proses belajar mengajar pada materi lingkunganhidup dan pembangunan berkelanjutan yang diajar dengan menerapkan model pembelajaran kooperatif tipe Think Pair Share (TPS) dapat dijelaskan berdasarkan hasil pengamatan pada setiap siklus baik siklus I maupun siklus II yang menunjukan peningkatan kearah yang lebih baik. Peningkatan aktivitas belajar siswa tersebut menunjukan adanya minat dan antusiasme siswa dalam mengikuti proses pembelajaran pada materi lingkungan hidup dan pembangunan berkelanjutan dengan menerapakan Model Pembelajaran Kooperatif tipe Think Pair Share (TPS).

Pada siklus I berdasarkan hasil analisis deskriptif terhadap aktivitas belajar siswa menunjukan skor ratarata aktivitas belajar siswa pada siklus I sebesar 2.74 yang berkategori Cukup. Pada siklus I ada beberapa aktivitas belajar siswa yang masih tergolong kurang dimana siswa belum terbiasa dengan Model Pembelajaran Kooperatif tipe Think Pair Share (TPS) pada materi pokok lingkungan hidup dan pembangunan berkleanjutan diantaranya: Siswa kurang menyimak dengan fokus saat pemeriksaan kehadiran dan menyiapkan diri untuk belajar, Siswa kurang termotivasi untuk belajar, siswa kurang mendengarkan menyampaikan tujuan pembelajaran yang akan dicapai, 
Siswa kurang menyimak dengan seksama pertanyaan yang berhubungan dengan materi yang akan disampaikan, siswa kurang melakukan refleksi atau evaluasi terhadap hasil pemecahan masalah yang telah mereka diskusikan, siswa kurang menyimpulkan pelajaran. Berdasarkan hasil refleksi pada siklus I ditemukan beberapa aktivitas siswa yang masih belum terlaksana dengan baik. Oleh karena itu dilakukan perbaikan pada siklus selanjutnya.

Pada siklus II dari hasil analisis deskriptif terhadap skor ratarata aktivitas belajar siswa pada siklus II menunjukan adanya peningkatan yang signifikan dari aktivitas belajar siswa siklus I, dimana skor rata-rata aktivitas belajar siswa pada siklus II sebesar 3,2 yang berkategori Baik. Hal ini menunjukan bahwa penelitian telah berhasil karena telah memenuhi standar minimal aktivitas siswa yaitu 3,0 .

\section{Aktivitas Mengajar Guru}

Berdasarkan permasalahan kedua yaitu bagaimana gambaran aktivitas mengajar guru dengan menerapkan Model Pembelajaran Kooperatif tipe Think Pair Share (TPS) pada materi lingkungan hidup dan pembangunan berkelanjutan, dapat dijelaskan berdasarkan hasil pengamatan aktivitas mengajar guru pada setiap siklus baik siklus I maupun siklus II yang menunjukan peningkatan kearah yang lebih baik.

Pada siklus I berdasarkan analisa deskriptif aktivitas guru menunjukkan skor rata-rata aktivitas guru sebesar 2,67 yang berkategori cukup dimana aktivitas guru pada siklus I yang masih rendah berdasarkan hasil refleksi diantaranya adalah: Guru kurang mempersilahkan siswa berdoa, guru kurang memberikan motivasi kepada siswa, guru kurang menyampaikan tujuan pembelajaran yang akan dicapai, guru kurang menyampaikan pertanyaan yang behubungan dengan materi yang akan disampaikan, Guru kurang memberi kesempatan kepada siswa untuk memikirkan sendiri jawaban dari permasalahan yang disampaikan dan meminta siswa untuk menulisakn hasil pemikiran masing-masing, guru kurang membantu siswa untuk melakukan refleksis atau evaluasi terhadap hasil pemecahan masalah yang telah mereka diskusikan, guru kurang membimbing siswa untuk menyimpulkan pelajaran.

Berdasarkan hasil refleksi terhadap aktivitas guru, dengan mengetahui kekurangan-kekurangan pada siklus I, guru memperbaiki cara mengajarkan materi pembelajaran yang sesuai dengan Model Pembelajaran Kooperatif tipe Think Pair Share (TPS) pada materi lingkungan hidup dan pembangunan berkelanjutan sehingga diharapkan pada pertemuan selanjutnya diperoleh peningkatan aktivitas guru pada siklus selanjutnya.

$\begin{array}{clr}\text { Pada } & \text { siklus } & \text { II aktivitas } \\ \text { mengajar } & \text { guru } & \text { menunjukan }\end{array}$ peningkatan yang signifikan, dimana pada siklus II skor rata-rata aktivitas guru memperoleh nilai sebesar 3,28 yang berkategori baik. Hasil analisis dan pengamatan pada siklus II ini menunjukan adanya peningkatan aktivitas mengajar guru dengan menerapkan Model Pembelajaran Kooperatif tipe Think Pair Share (TPS) pada materi lingkungan hidup dan pembangunan berkelanjutan. Hal ini menunjukan bahwa penelitian telah berhasil karena telah memenuhi standar minimal aktivitas mengajar guru yaitu 3,0. 


\section{Hasil Belajar Siswa}

Berdasarkan permasalahan ketiga yaitu apakah ada peningkatan hasil belajar siswa yang diajar dengan penerapan Model Pembelajaran Kooperatif tipe Think Pair Share (TPS) pada materi lingkungan hidup dan pembangunan berkelanjutan pada siswa kelas VIII A SMP Negeri 1 Kambowa, dapat dijelaskan bahwa berdasarkan hasil analisis deskriptif kuantitatif yang dilakukan terhadap hasil belajar siswa pada setiap siklus cenderung mengalami peningkatan kearah yang lebih baik.

Pada siklus I berdasarkan hasil tes belajar siswa diperoleh nilai minimum sebesar 40; nilai maksimum 80; rata-rata hasil belajar siswa 63,84 Secara klasikal dari 26 siswa yang mencapai persentase ketuntasan hasil belajar yaitu 14 orang siswa atau $53,84 \%$ yang mencapai nilai $\geq 65$ sesuai dengan nilai KKM IPS dan terdapat 12 orang siswa dengan persentase $46,15 \%$ siswa yang nilainya belum mencapai KKM yang ditentukan oleh sekolah yaitu 65. Persentase ketuntasan pada siklus I ini belum mencapai target peneliti yaitu mencapai ketuntasan belajar secara klasikal minimal $80 \%$.

Berdasarkan refleksi dengan melihat aktivitas siswa dan hasil belajar pada siklus I tersebut, dapat diambil suatu kesimpulan bahwa dalam proses pembelajaran ini tampak bahwa siswa kurang kosentrasi dalam berdoa, Siswa kurang menyimak dengan fokus saat pemeriksaan kehadiran dan menyiapkan diri untuk belajar, Siswa kurang termotivasi untuk belajar, siswa kurang mendengarkan menyampaikan tujuan pembelajaran yang akan dicapai, Siswa kurang menyimak dengan seksama pertanyaan yang berhubungan dengan materi yang akan disampaikan, Siswa kurang untuk memikirkan sendiri jawaban dari permasalahan yang disampaikan guru dengan menuliskan hasil pemikiran masing-masing, siswa kurang mendiskusikan hasil masing-masing dengan pasangannya, siswa kurang menyimpulkan pelajaran, siswa kurang menulis soal untuk dikerjakan dirumah, Siswa kurang mendengarkan penyampaian materi yang harus dipelajari untuk pertemuan berikutnya, siswa kurang fokus untuk menjawab salam.

Setelah melakukan analisis dan refleksi hasil belajar siswa pada siklus I, guru mata pelajaran dan peneliti mencoba melakukan perbaikan dalam proses belajar mengajar pada siklus selanjutnya agar siswa yang belum memenuhi ketuntasan belajar dapat meningkat seperti yang diharapkan.

Pada siklus II berdasarkan hasil tes belajar siswa pada akhir siklus, terlihat bahwa hasil belajar siswa memperoleh nilai minimum 50 nilai maksimum 90; nilai rata-rata hasil belajar siswa sebesar 72,11 Terdapat 22 siswa yang memperoleh nilai $\geq 65$ atau ketuntasan belajar secara klasikal sebesar $84,61 \%$ sedangkan jumlah siswa yang hasil belajarnya di bawah KKM atau yang memperoleh nilai $<65$ sebanyak 4 orang atau $15,38 \%$ yang belum tuntas. Dari hasil tersebut menunjukan peningkatan hasil belajar yang signifikan dari siklus I ke siklus II, walaupun masih ada 4 siswa yang belum mencapai ketuntasan belajar.

Pada siklus II target ketuntasan hasil belajar siswa telah tercapai yaitu $84,61 \%$ siswa telah tuntas dalam hasil belajarnya. Hal ini peneliti dianggap telah berhasil mencapai targetnya. Dalam penelitian ini keberhasilan 
siswa dalam tes hasil belajar siklus II memberikan gambaran bahwa penerapan Model Pembelajaran Koopertif tipe Think Pair Share (TPS) pada materi lingkungan hidup dan pembangunan berkelanjutan mampu meningkatkan hasil belajar siswa.

Dengan demikian jawaban atas permasalahan penelitian telah ditemukan yaitu pembelajaran dengan menerapkan Model Pembelajaran Kooperatif tipe Think Pair Share (TPS) berhasil meningkatkan hasil belajar IPS siswa kelas VIII A SMP Negeri 1 Kambowa khususnya pada materi lingkungan hidup dan pemabngunan berkelanjutan

\section{KESIMPULAN}

Berdasarkan rumusan masalah dan hasil analisis data dalam penelitian ini dapat ditarik beberapa kesimpulan sebagai berikut: 1) Gambaran aktivitas belajar siswa dengan menerapkan Model Pembelajaran Kooperatif tipe Think Pair Share (TPS) materi lingkungan hidup dan pembangunan berkelanjutan pada setiap siklus cenderung meningkat. Hal ini ditunjukan dengan skor rata-rata pada setiap siklus, dimana pada siklus I skor rata-rata aktivitas belajar siswa adalah 2,7 yang termasuk kategori Cukup meningkat padasiklus II menjadi 3,21 yang termasuk pada kategori Baik. 2) Gambaran aktivitas mengajar guru dengan menerapkan Model Pembelajaran Kooperatif tipe Think Pair Share (TPS) pada materi lingkungan hidup dan pembangunan berkelanjutan pada setiap siklus cenderung meningkat. Hal ini ditunjukan dengan skor rata-rata pada setiap siklus, dimana pada siklus I skor rata-rata aktivitas mengajar guru adalah 2,67 yang termasuk kategori
Cukup dan meningkat pada siklus II menjadi 3,28 yang berkategori Baik. 3) Hasil belajar IPS siswa kelas VIII A SMP Negeri 1 Kambowa meningkat sebesar 30,77\% dengan menerapkan Model Pembelajaran Kooperatif tipe Think Pair Share (TPS) pokok bahasan Lingkungan hidup dan pembangunan berkelanjutan. Dimana ketuntasan belajar pada siklus I sebesar $53,84 \%$ dan pada siklus II sebesar 84,61 .

\section{DAFTAR PUSTAKA}

Baharuddin dan Wahyuni, Nur. 2012. Teori Belajar \& Pembelajaran. Jogjakarta:Ar-Ruzz Media.

Hamalik, Oemar. 2009. Pendekatan Baru Strategi Belajar Mengajar Berdasarkan CBSA. Bandung: Sinar Baru Algesindo.

Hasbullah. 2009. Dasar-dasar Ilmu Pendidikan. Jakarta: Raja Grafindo Persada dalam konsep dasar ilmu pendidikan. Alfabeta

Ibrahim, M. 2000. Pembelajaran kooperatif. Surabaya: Universitas Press.

Nurhadi, dkk. 2003. Pembelajaran kontextual dan penerapannya dalam KBK.Malang:

Rifa'i, Achmad dan Anni, Catharina Tri. 2009. Psikologi Pendidikan. Semarang: UNNES PRESS.

Rusmono. 2012. Strategi Pembelajaran dengan Problem Based Learning Itu Perlu. Bogor: Ghalia Indonesia. 
Jurnal Penelitian Pendidikan Geografi Volume 3 No. 4 Oktober 2018

Sagala, Syaiful. 2011. Konsep \& Makna Pembelajaran.

Bandung: Alfabeta

Sanjaya, wina. 2011. Strategi pembelajaran berorientasi standar proses pendidikan. Jakarta: kencana.

Suprijono, Agus. 2009. Cooperative Learning Teori dan Aplikasi Paikem. Yogyakarta: Pustaka Belajar. 